\title{
ИЗУЧЕНИЕ АНТИМИКРОБНОЙ АКТИВНОСТИ НОВЫХ ПРОИЗВОДНЫХ ХИНАЗОЛИН-4(3Н)-ОНА В ОТНОШЕНИИ ГРАМОТРИЦАТЕЛЬНЫХ И ГРАМПОЛОЖИТЕЛЬНЫХ ПАТОГЕННЫХ МИКРООРГАНИЗМОВ
}

\author{
А.А. Старикова ${ }^{1}$, Н.М.Габитова ${ }^{1,3}$, Д.В.Мережкина ${ }^{2}$, А.А.Озеров ${ }^{2}$, \\ М.А.Самотруева', И.Н.Тюренков²
}

${ }^{1}$ ФГБОУ ВО «Астраханский государственный медицинский университет» Министерства здравоохранения Российской Федерации

414000, Россия, г. Астрахань, ул. Бакинская, 121.

2ФГБОУ ВО «Волгоградский государственный медицинский университет»

Министерства здравоохранения Российской Федерации

400131, Россия, г. Волгоград, Павших Борцов пл., 1.

${ }^{3}$ Федеральное государственное бюджетное учреждение «Научно-исследовательский институт по изучению лепры» Министерства здравоохранения Российской Федерации 414057, Россия, г. Астрахань, проезд Николая Островского, 3.

DOI: 10.19163/MedChemRussia2021-2021-109

E-mail:alhimik.83@mail.ru

Проблема поиска веществ, проявляющих противомикробную активность и не вызывающих резистентность у патогена, является актуальной и требует незамедлительного решения.Производные хиназолин-4(3Н)-она, как соединения с уникальным химическим строением, проявляющие широкий спектр фармакологической активности, могут быть рекомендованы в качестве противомикробных агентов,оказывающих действие как в отношении грамположительных, так и грамотрицательных бактерий.<smiles>[R]C(=O)C([R])n1cnc2c([R])cc([R])cc2c1=O</smiles>

Puс. 1. Общая формула производных хиназолин-4(3Н)-она

В результате первичного микробиологического скрининга установлено, что вещество, содержащее амидную группу, связанную с ядром хиназолинона и бензойным кольцом, проявляет выраженную бактериостатическую активность в отношении S. aureus, E. coli u K. Pneumoniae, и способно оказывать бактерицидное действие на P. mirabilis. Доказана чувствительность S. pneumonia, E. coli и K. Рneumoniaeк производному хиназолин4(3Н)-она, содержащему нафтильный радикал. Учитывая способность хиназолиноновых соединений ингибировать синтез ДНК за счет расщепления бактериальной ДНК-гиразы и топоизомеразы, можно предполагать, что азотсодержащий электронодонорный заместитель участвует в образовании водородной связи с активным сайтом фермента. Присутствие нафтильного радикала в молекуле способствует увеличению степенилипофильности вещества, вследствие чего повышается адсорбция соединения клеткой за счет возникновения прочных гидрофобных взаимодействий.

$$
-109-
$$

